\title{
Socio-Economic and Constraints Status of Impact of Integrated Watershed Development Programme in Nagaland, India
}

\author{
S. Kanitoli Chishi and Amod Sharma* \\ Department of Agricultural Economics, Nagaland University SASRD Medziphema Campus, \\ District: Dimapur - 797 106, Nagaland, India \\ *Corresponding author
}

\section{A B S T R A C T}

The present study to access the Impact of watershed on the level of economics with especial reference to the beneficiaries and non-beneficiaries for the purpose two districts

\section{Keywords}

IWDP, impact, economics, beneficiaries, nonbeneficiaries

Article Info

Accepted:

12 October 2018

Available Online:

10 November 2018 from the Nagaland state viz., Dimapur and Zunheboto were selected purposely due to the maximum number of area covered under watershed in the zone further two blocks from each district were randomly selected which was finally having 8 numbers of watersheds areas were selected. In the second stage of sampling a multi stage random sampling was used for the selection of beneficiary and non-beneficiary viz., 160 respondents (80 beneficiaries and 80 non-beneficiaries) were selected randomly from identified watershed areas. Study reveals that the net returns of overall net returns on the beneficiaries was Rs $18,31,370.00 /$ - as compared to Rs $11,56,914.00 /-$ the non-beneficiaries. While on the large farms was found to highest percent increase in net return over small, semi-medium and medium farmers, respectively. The main constraints faced by the farmers in the implementation of Integrated watershed management Programme is the infra-structural problem of lack of machines and equipment, lack of awareness about finance facilities, lack of transportation facilities etc.; will timely dissemination of the information to the farmers. Easy availability of market and knowledge on post-harvest management will help boost the economy of the rural areas in Nagaland.

\section{Introduction}

Water is life. It originates in water if at all it ends, it will end with water. The role of water is felt everywhere, its scarcity causes drought, famines, its' excess causes flood and deluge. Water scarcity in some parts and flood elsewhere has become the single greatest threat to food security, human health and natural ecosystems (Pannu et al., 2017). Satisfying human needs for food, water and economic opportunity while simultaneously maintaining the viability of water dependent ecosystem shall be the major challenge of the century. Water is possibly our most precious natural resource. The abundance and quality of water drives all human system and those of most other organisms (Dhakre and Sharma, 2010; Anon. 2016).

Effective use of land and water is fundamental to growth and sustainable development (Mishra, 2014). The concept of watershed management has evolved to ensure effective 
use of both natural and social capitals. Thus, the watershed development programmes include land, water and human resources as essential components. The watershed programme is primarily a land based programme, which is increasingly being focussed on water, with its main objective being to enhance agricultural productivity through increased in situ moisture conservation and protective irrigation for socio-economic development of rural people (Raju, 2012; Walling et al., 2017; Sangtam and Sharma, 2018).

Watershed is defined as a hydro-geological unit area from which the rainwater drains through a single outlet. Watershed development refers to the conservation, regeneration and judicious use of all the natural resources (like land, water, plants, animals) by human beings (Walling and Sharma, 2015). Watershed management brings about best possible balance between natural resources on the one side and human beings on the other. Human beings and the ecology are interdependent.

The changes in the environment directly affect the lives of the people depending on it. A degraded environment means a degraded quality of life of the people. This degradation can be tackled effectively through the holistic development of the watershed. A watershed provides a natural geo-hydrological unit for planning any developmental initiative (Sharma, 2011b; Shuya and Sharma, 2018). The approach would be treatment from "ridge to valley". The present study having the two specific objectives:

To examine the socio-economic status of the sample farmers, and

To study the constraints faced by the sample farmers in the implementation of Integrated Watershed Management Programme (IWMP).

\section{Materials and Methods}

The present study is related to IWMP scheme, which is working as per the guideline of Central government with the help of Ministry of Agriculture, Government of India. Development projects require long period of time to reap benefits. Therefore for economic appraisal of development projects, it is essential that the project has been in operation for quite some time. Since the intensive IWMP started in 2008-09, so it is worth, while to study its impact. Since the data of the initial period cannot be compared with the data of recent years. It is more scientific and practical to compare the economy of the beneficiaries and non-beneficiaries covered in the area of IWMP schemes. The IWMP was launched in 2008-09 in all 11 district viz., Dimapur, Kohima, Kiphire, Longleng, Mokokchung, Mon, Phek, Peren, Tuensang, Wokha and Zunheboto of Nagaland (Anon., 2017), out of these districts two districts namely, Zunheboto and Dimapur districts of Nagaland selected because of the fact that it is expected to provide all the relevant information and hence can conveniently be obtained for conducting this study. The project area also has a good network of infrastructure and allied activities related to the scheme such as development agencies, nationalized banks, well-established marketing and communication facilities etc. Keeping all the above facts, both districts of Nagaland are therefore purposively selected to conduct this study.

\section{Zunheboto district}

Zunheboto is one of the under developed district of Nagaland having a total geographical area of 1,36,455 ha. Zunheboto District is bounded by the state of Assam to its North. Tuensang to its east, Mokokchung to its South and Wokha and Assam to its West, and lies between 93.53 and 94.53 degrees longitude and 25.56 degrees latitude. In this 
district all 4 types of agro-climatic conditions are present.

\section{Dimapur district}

Dimapur district is situated in the SouthEastern part of Nagaland, bounded by Kohima districts inthe North, Assam state in the South and Peren district in the West, Earlier a part of Kohima district, it was made a separate district on December 21, 1999. It is inhabited by the mixed type of populations. It is a basically plain area district rich in agricultural and horticultural production base area and surrounded by important river namely Dhansiri, Dimapur is most development district of the State.

\section{Selection of blocks}

Two blocks from each district will be selected randomly for the present study as those are well covered by IWMP programme.

\section{Selection of villages}

Altogether eight villages were selected randomly from each district while four villages from each block will be selected and listed which would be obtained from the office of SDO (Civil) Rural Development (RD) Block headquarter and other related offices. However, it is proposed to select four villages from each block randomly covered for IWMP scheme.

\section{Selection of farmers}

After selection of the villages, list of beneficiaries and non-beneficiaries of IWMP will be prepared from each of the selected village. In order to have representative sample from each village a sample of 20 numbers of cases of IWMP, out of that 10 from beneficiaries and 10 from non-beneficiaries will be drawn following the purposively random sampling method. This will result in selection of 160 respondents from 8 villages, out of which 80 will be beneficiaries of IWMP scheme and 80 will be non-beneficiaries of IWMP scheme.

\section{Data collection}

The study will be based on primary and secondary data, Secondary data will be collected from secondary sources viz, office of the Project Director, IWMP Zunheboto and Dimapur various published level etc. will be conducted.

Besides, data on demographic features, land use pattern, livestock population, climate, rainfall, area under irrigation; institutional infrastructure etc. will also be collected from various statistical abstracts of the districts and state which will enlighten the socio-economic and infrastructural scenario of the area under study. The primary data will be collected through pre-tested and pre-structured schedules and questionnaires' especially designed for this study.

\section{Results and Discussion}

Table 1 reveals that the classification of respondent according to age, sex, educational qualification and family size. In respect of age categorization of the respondents, a nominal level of measurements was adopted to classify the respondents. The ministry of Human Resource Development in India, Act 1985 considered in India a person in the age group 15 to 35 years as young or youth group, 36 to 50 age group as middle and 51 and above as old age group, so as per these guidelines, the age categorization of the sample respondents was done. The active age group was found to be the middle age group. For the beneficiaries 53.75 per cent of the respondent belongs to old age group (51 years and above), followed by 38.75 per cent belongs to middle age group 
(36 to 50 years) and only 7.50 per cent belongs to young age group (up to 35 years), respectively (Sharma, 2011a).

While for the non-beneficiaries 46.25 per cent of the respondent belongs to middle age group (36 to 50years), followed by 45.00 per cent respondent belongs old age group (51 years and above) and only 8.75 per cent of the respondent belongs to young age group (up to 35 years). Further 89.37 per cent of the respondent belongs to the male category and the remaining 10.63 per cent of the respondent belongs to the female category. 46.87 per cent of the respondent had family size of 6 to 8 , followed by 43.75 percent having family size of less than 6 and only 9.38 per cent of the respondent had family size 9 and above, respectively.

The educational qualification of the respondent can be viewed from the table shows very low illiteracy rate of only 13.75 per cent and high literacy rate of 86.25 per cent. Out of 86.25 per cent literacy rate 33.75 per cent of the respondent studied up to primary level, 30.00 per cent of the respondent studied up to higher secondary / High school level and the remaining 22.50 per cent had studied up to graduate level and above. Comparatively non-beneficiaries had more illiterate respondent (15.00 per cent) against 12.50 per cent of the beneficiaries, similar studies were conducted by the Sharma (2002); Sharma (2004).

Table 2 reveals that the classification based on occupation and land holding of the respondent 50.00 per cent of the beneficiaries are engaged primarily in agriculture, 25.00 per cent are engaged in service sector, 16.00 per cent are engaged in business and only 5.00 per cent are engaged in other sector, while for the nonbeneficiaries 45.00 per cent are engaged in service sector, followed by 40.00 per cent in agriculture, only 3.75 per cent are engaged in business sector and 11.25 per cent are engaged in other sector. The secondary occupation of the respondent are mostly engaged in business sector with 54.38 per cent, followed by 23.75 per cent in agriculture, 11.25 per cent in business and only 10.62 per cent in other sectors, respectively. In case of land holding, 39.37 per cent of the respondent belongs to medium group farmers, 30.63 per cent belongs to large farm groups, 24.37 per cent belongs to semi-medium group and only 5.63 per cent belongs to small farm group. Comparatively the beneficiaries are mostly in the medium farm groups (41.25 per cent) against 39.37 per cent of the non-beneficiaries, respectively. Similar studies were carried by Shuya and Sharma (2014); Sharma et al., (2015); Pongener and Sharma (2018)

Table 3 reveals that the livestock pattern of the farmer is depicted. The sample farmers were fond of rearing livestock animals or poultry birds such as pig, chicken, cow, goat, cat and dog. Chicken is found to be the most important livestock reared in terms of number followed by pig, duck, cow, goat, dog, fishery and lesser number of cats. Usually Nagaland is the state, were livestock is predominately to every house-hold and non-vegetarian eater to every meal. Similar studies were carried out by Sharma (2014); Sharma et al., (2016).

Table 4 reveals that the Annual gross return generated, expenditure incurred and resultant net return accrued to non-beneficiary and beneficiary farmers from crops (ha / year). The beneficiaries are higher than the nonbeneficiaries. The overall net returns of the beneficiaries is Rs 18,31,370.00/- as compared to Rs $11,56,914.00 /-$ of the non-beneficiaries. The Gross Income was found minimum (Rs 42,800.00/-) on small farmers and maximum (Rs 6,29,114.00/-) on large non-beneficiaries farmers, which was least as compare to beneficiaries small and large farmers per ha / year, respectively. 
Table.1 Socio-economic variables of beneficiaries and non-beneficiaries of IWDP

\begin{tabular}{|c|c|c|c|c|c|c|c|}
\hline \multirow[t]{2}{*}{$\mathbf{S ~ N}$} & \multirow[t]{2}{*}{ Particulars } & \multicolumn{2}{|c|}{ Beneficiaries } & \multicolumn{2}{|c|}{ Non-beneficiaries } & \multicolumn{2}{|c|}{ Total } \\
\hline & & Freq. & Per cent & Freq. & Per cent & Freq. & Per cent \\
\hline (A). & \multicolumn{7}{|l|}{ AGE: } \\
\hline 1. & Young $(<35$ years $)$ & 6 & 7.50 & 8 & 10.00 & 14 & 8.75 \\
\hline 2. & Middle (36-50 years) & 31 & 38.75 & 43 & 53.75 & 74 & 46.25 \\
\hline 3. & Old (51 \& above) & 43 & 53.75 & 29 & 36.25 & 72 & 45.00 \\
\hline \multicolumn{2}{|r|}{ Total } & 80 & 100.00 & 80 & 100.00 & 160 & 100.00 \\
\hline (B). & \multicolumn{7}{|l|}{ SEX: } \\
\hline 1. & Female & 9 & 11.25 & 8 & 10.00 & 17 & 10.63 \\
\hline 2. & Male & 71 & 88.75 & 72 & 90.00 & 143 & 89.37 \\
\hline \multicolumn{2}{|c|}{ Total } & 80 & 100.00 & 80 & 100.00 & 160 & 100.00 \\
\hline (C). & \multicolumn{7}{|l|}{ FAMILY SIZE: } \\
\hline 1. & Less than 6 & 31 & 38.75 & 39 & 48.75 & 70 & 43.75 \\
\hline 2. & 6 to 8 members & 42 & 52.50 & 33 & 41.25 & 75 & 46.87 \\
\hline 3. & 9 members \& above & 7 & 8.75 & 8 & 10.00 & 15 & 9.38 \\
\hline \multicolumn{2}{|r|}{ Total } & 80 & 100.00 & 80 & 100.00 & 160 & 100.00 \\
\hline (D). & \multicolumn{7}{|c|}{ EDUCATIONAL QUALIFICATION: } \\
\hline 1. & Illiterate & 10 & 12.50 & 12 & 15.00 & 22 & 13.75 \\
\hline 2. & Primary School & 26 & 32.50 & 28 & 35.00 & 54 & 33.75 \\
\hline 3. & High School & 24 & 30.00 & 24 & 30.00 & 48 & 30.0 \\
\hline 4. & Graduate \& above & 20 & 25.00 & 16 & 20.00 & 36 & 22.50 \\
\hline
\end{tabular}

Table.2 Respondent demography according to occupation and land holding

\begin{tabular}{|c|c|c|c|c|c|c|c|}
\hline \multirow{2}{*}{$\begin{array}{l}\text { SL. } \\
\text { N. }\end{array}$} & \multirow[t]{2}{*}{ Occupation } & \multicolumn{2}{|c|}{ Beneficiaries } & \multicolumn{2}{|c|}{ Non-beneficiaries } & \multicolumn{2}{|c|}{ Total } \\
\hline & & Freq. & Per cent & Freq. & Per cent & Freq. & Per cent \\
\hline (A) & \multicolumn{7}{|c|}{ Primary Occupation: } \\
\hline 1. & Agriculture & 40 & 50.00 & 32 & 40.00 & 72 & 45.00 \\
\hline 2. & Service & 20 & 25.00 & 36 & 45.00 & 56 & 35.00 \\
\hline 3. & Business & 16 & 20.00 & 3 & 3.75 & 19 & 11.87 \\
\hline 4. & Others & 4 & 5.00 & 9 & 11.25 & 13 & 8.13 \\
\hline & Total & 80 & 100.00 & 80 & 100.00 & 160 & 100.00 \\
\hline (B) & \multicolumn{7}{|c|}{ Secondary occupation: } \\
\hline 1. & Agriculture & 20 & 25.00 & 18 & 22.50 & 38 & 23.75 \\
\hline 2. & Service & 2 & 2.50 & 16 & 20.00 & 18 & 11.25 \\
\hline 3. & Others & 9 & 11.25 & 8 & 10.00 & 17 & 10.62 \\
\hline & Total & 80 & 100.00 & 80 & 100.00 & 160 & 100.00 \\
\hline (C) & \multicolumn{7}{|l|}{ Land Holding: } \\
\hline 1. & Small farmers & 5 & 6.25 & 4 & 5.00 & 9 & 5.63 \\
\hline 2. & Semi-Medium & 16 & 20.00 & 23 & 28.75 & 39 & 24.37 \\
\hline 3. & Medium & 33 & 41.25 & 30 & 37.50 & 63 & 39.37 \\
\hline 4. & Large farmers & 26 & 32.50 & 23 & 28.75 & 49 & 30.63 \\
\hline & Total & 80 & 100.00 & 80 & 100.00 & 160 & 100.00 \\
\hline
\end{tabular}


Table.3 Livestock pattern of the sample farmers

\begin{tabular}{|l|l|c|c|c|c|c|c|}
\hline S. & Particulars & \multicolumn{2}{|c|}{ Beneficiaries } & \multicolumn{2}{|c|}{ Non-beneficiaries } & \multicolumn{2}{|c|}{ Total } \\
\hline N. & & Numbers & Per cent & Numbers & Per cent & Numbers & Per cent \\
\hline 1. & Chicken & 1215 & 61.36 & 1013 & 54.35 & 2228 & 57.96 \\
\hline 2. & Pig & 268 & 13.54 & 280 & 15.02 & 548 & 14.26 \\
\hline 3. & Duck & 162 & 8.19 & 235 & 12.61 & 397 & 10.33 \\
\hline 4. & Goat & 80 & 4.04 & 96 & 5.15 & 176 & 4.58 \\
\hline 5. & Cow & 98 & 4.94 & 105 & 5.63 & 203 & 5.28 \\
\hline 6. & Dog & 91 & 4.60 & 78 & 4.18 & 169 & 4.39 \\
\hline 7. & Cat & 26 & 1.31 & 17 & 0.91 & 43 & 1.12 \\
\hline 8. & Fishery & 40 & 2.02 & 40 & 2.15 & 80 & 2.08 \\
\hline & Total & 1980 & 100.00 & 1864 & 100.00 & 3844 & 100.00 \\
\hline
\end{tabular}

Table.4 Gross income generated, expenditure incurred and net return accrued to non-beneficiary and beneficiary farmers from crops (ha / year):

\begin{tabular}{|c|c|c|c|c|c|c|c|}
\hline \multirow{2}{*}{$\begin{array}{l}\text { Sl. } \\
\text { No }\end{array}$} & \multirow[t]{2}{*}{ Category } & \multicolumn{3}{|c|}{ Non-Beneficiaries } & \multicolumn{3}{|c|}{ Beneficiaries } \\
\hline & & $\begin{array}{l}\text { Gross } \\
\text { Income }\end{array}$ & $\begin{array}{l}\text { Expendi } \\
\text { ture }\end{array}$ & $\begin{array}{c}\text { Net } \\
\text { returns }\end{array}$ & $\begin{array}{c}\text { Gross } \\
\text { Income }\end{array}$ & $\begin{array}{l}\text { Expendit } \\
\text { ure }\end{array}$ & $\begin{array}{l}\text { Net } \\
\text { returns }\end{array}$ \\
\hline 1. & Small farmers & 42,800 & 15,300 & 27,500 & 52,000 & 13,500 & 38,500 \\
\hline 2. & Semi-medium & $4,52,580$ & $2,30,080$ & $2,22,500$ & $2,97,680$ & $1,27,380$ & $1,70,300$ \\
\hline 3. & Medium & $5,85,110$ & $1,65,010$ & $4,20,100$ & $7,65,040$ & $2,57,000$ & $5,08,040$ \\
\hline 4. & Large farmers & $6,29,114$ & $2,25,100$ & $4,04,014$ & $\begin{array}{r}14,54,08 \\
0\end{array}$ & $3,14,000$ & $\begin{array}{r}11,40,08 \\
0\end{array}$ \\
\hline & Overall & $\begin{array}{r}17,09,60 \\
4\end{array}$ & $5,52,690$ & $\begin{array}{r}11,56,91 \\
4\end{array}$ & $\begin{array}{r}25,62,80 \\
0\end{array}$ & $7,31,430$ & $\begin{array}{r}18,31,37 \\
0\end{array}$ \\
\hline
\end{tabular}

Table.5 Change in annual net return of beneficiary farmers over non-beneficiary farmers from crops on different size group of farms (ha / annum)

\begin{tabular}{|l|l|r|r|r|r|}
\hline $\begin{array}{l}\text { S1. } \\
\text { No. }\end{array}$ & Category & $\begin{array}{l}\text { Average net } \\
\text { return of } \\
\text { beneficiary }\end{array}$ & $\begin{array}{l}\text { Average net } \\
\text { return of } \\
\text { non- } \\
\text { beneficiary }\end{array}$ & $\begin{array}{l}\text { Absolute increase } \\
\text { in net return of } \\
\text { beneficiary over } \\
\text { non-beneficiary }\end{array}$ & $\begin{array}{l}\text { Per } \\
\text { increase in } \\
\text { net return }\end{array}$ \\
\hline 1. & Small farmers & $7,700.00$ & $6,875.00$ & 825.00 & $\mathbf{2 . 8 0}$ \\
\hline 2. & Semi-Medium & $10,643.75$ & $9,673.91$ & 969.84 & $\mathbf{3 . 2 9}$ \\
\hline 3. & Medium farmers & $15,395.15$ & $14,003.26$ & $1,391.89$ & $\mathbf{4 . 7 2}$ \\
\hline 4. & Large farmers & $43,849.23$ & $17,565.83$ & $26,283.40$ & $\mathbf{8 9 . 1 9}$ \\
\hline & Overall & $\mathbf{7 7 , 5 8 8 . 1 3}$ & $\mathbf{4 8 , 1 1 8 . 0 0}$ & $\mathbf{2 9 , 4 7 0 . 1 3}$ & $\mathbf{1 0 0 . 0 0}$ \\
\hline
\end{tabular}


Table.6 Constraint faced by beneficiaries in adoption of IWMP

\begin{tabular}{|c|c|c|c|c|}
\hline Sl. No. & Constraints & Number & Percentage & Rank \\
\hline A. & \multicolumn{4}{|l|}{ Technological constraints: } \\
\hline 1. & Lack of knowledge about improved varieties & 52 & 65.00 & XI \\
\hline 2. & $\begin{array}{l}\text { Non availability of watershed based production } \\
\text { technology }\end{array}$ & 46 & 57.50 & XII \\
\hline 3. & Lack of training facilities & 45 & 56.25 & XIII \\
\hline 4. & Lack of improved water harvesting technologies & 66 & 82.50 & VI \\
\hline 5. & Technical knowledge about the bund & 72 & 90.00 & III \\
\hline B. & \multicolumn{4}{|l|}{ Economic constraints: } \\
\hline 1. & Lack of awareness about finance facilities & 75 & 93.75 & II \\
\hline 2. & Unavailability of finance in time & 70 & 87.50 & IV \\
\hline 3. & Fragmentation of land holding & 50 & 62.50 & $\mathbf{X}$ \\
\hline 4. & High inputs cost viz; seeds, fertilizers etc & 48 & 60.00 & XI \\
\hline C. & \multicolumn{4}{|l|}{ Institutional constraints: } \\
\hline 1. & Lack of training institutes & 68 & 85.00 & V \\
\hline 2. & Lack of extension services / active workers & 30 & 37.50 & XIV \\
\hline 3. & Distance between training institution and village & 70 & 87.50 & IV \\
\hline D. & \multicolumn{4}{|l|}{ Infra-structural constraints: } \\
\hline 1. & Un timely irrigation facilities & 61 & 76.25 & VII \\
\hline 2. & $\begin{array}{l}\text { Uncertainty about the availability of irrigation } \\
\text { water }\end{array}$ & 58 & 72.50 & VIII \\
\hline 3. & Inadequate supply of fertilizers, seeds etc. & 50 & 62.50 & $\mathbf{X}$ \\
\hline 4. & Lack of transportation facilities & 75 & 93.75 & II \\
\hline 5. & Lack of marketing facilities & 72 & 90.00 & III \\
\hline 6. & Lack of machinery / equipments used etc; & 76 & 95.00 & I \\
\hline 7. & Lack of information system etc & 75 & 93.75 & II \\
\hline
\end{tabular}

Even the expenditure was found to be more on beneficiaries (Rs. 7,31,430.00/-) as compare to non-beneficiaries (Rs. $5,52,690.00 /-)$ per ha / year, respectively. While the net returns was also found to be maximum on beneficiaries ranging from Rs. $38,500.00 /-$ to Rs. $11,40,080.00 /-)$ on as compare to ranging from Rs. $27,500.00 /-$ to Rs $11,56,914.00 /-$ on non-beneficiaries, respectively. Similar studies were carried out by Sharma (2014).

Table 5 reveals the percentage gains ranging from 2.80 per cent on small farmers being minimum to 89.19 per cent as maximum on large farmers on beneficiaries over the non- beneficiaries. While, the average annual net return of beneficiary over non-beneficiary from crops enterprise on different size group of farms was Rs. $825.00 /-$ to Rs. $26,283,40 /$. Also it is found that large farmers having the highest percentage of increase in net return over small, semi-medium and medium farmers, respectively.

Table 6 reveals the constraints faced by the beneficiaries in the implementation of Integrated Watershed Management Programme (IWMP) to understand it at grassroot level it was categorized into four groups viz., technological, economics, financial and infrastructural. The foremost constraints will 
be 95.00 per cent of the respondent faced as infra-structural, lack of machines and equipment etc., second constraints will be followed by 93.75 per cent of respondents felt that there is lack of awareness about finance facilities, followed by the lack of transportation facilities and lack of information system will be 90.00 per cent faced the technological gap of lack of knowledge about bunds. Unavailability of finance in time and distance between training institution and village will be 87.50 per cent, lack of training institutes will be considered as fifth constraints as 85.00 per cent and also unavailability of marketing facilities, only 37.50 per cent faced the problem of inactive extension workers or services, it implies that there are active workers who are easily accessible, respectively. Similar studies were carried out by Sharma and Sharma (2018) Tangjang and Sharma (2018).

The main conclusion emerged from the present study is that the beneficiaries mostly belong to the old age group, the family size of the study is found from medium group with a high literacy rate.

Agriculture was found to be primary occupation for the beneficiary with primary occupation with the maximum average size of land holding for beneficiary for small, semimedium, medium and large farmers, so, the land holding is found to increase with the increase in farm size. The livestock rearing has economic importance for both the beneficiary and non-beneficiary group with rearing of poultry as the most important enterprise, respectively. The net return of the beneficiaries was found to be higher than the non-beneficiaries. The main constrains was lack of machinery and equipment, lack of awareness about finance facilities, lack of transportation facilities, lack of information system, inactive extension workers or services, respectively.

\section{References}

Analogous. 2016. Agricultural Situation in India. Directorate of Economics and Statistics. Ministry of Agriculture, New Delhi.

Analogous. 2017. Statistical Hand of Nagaland Published by Directorate of Economics and Statistics (various issues), Kohima, Nagaland.

Dhakre, D. S. and Sharma, Amod. 2010. Socio-Economic Development in India. Environment and Ecology. 4(1): 24692472.

Mishra, A., Pattnaik, B. R. and Ray, Plabita. 2014. Impact of Watershed Development Programme on Socioeconomic Development of the People. Journal of Extension Education. 39(1): 182-189.

Pannu, H. R., Lakhera, J. P., Yadav, J. P. and Jeengar, K. C. 2017. Constraints Perceived in Adoption of Indigenous Water Harvesting Practices. Indian Research Journal of Extension Education. 17(2): 121-124.

Pongener, Bendangjungla and Sharma, Amod. 2018. Constraints Faced by the Fishery Enterprises: A SWOC Analysis. IJCMAS. 7(5). May: 1595-1603.

Raju, T., Sharma, J. P., Singh, Premlata Lata. and Padaria, R. N. 2012. Socioeconomic Impact of Watershed Development. Journal of Community Mobilization and Sustainable Development. 7(2): 158-164.

Sangtam, Likhase. L. T. and Sharma, Amod. 2015. Impact of Bank Finance on Employment and Income through Piggery Enterprise in Nagaland. EPRAIJEBR. 3(11). Nov: 273-276.

Sharma, A. 2002. Source and Knowledge on beneficiaries about the purpose of credit - A case study of Agra Region of Uttar Pradesh. Journal of Interacademica. 6(3). July: 374-379. 
Sharma, A. 2004. Constraints of Fish Production - A case study in rainfed areas of Uttar Pradesh. Journal of Interacademica. 8(4). October: 639643.

Sharma, A. and Sharma, Anamika. 2008. Problems faced by the farmers in adoption of improved maize cultivation practices in hills. TJRAR. 8(2): 22-23.

Sharma, Amod. 2011. Economic and Constraints of King Chilli Growers in Dimapur District of Nagaland. Journal of Interacademicia. 15(4): 710-719.

Sharma, Amod. 2012. Inter-state Disparities in Socio-economic Development in North East Region of India. Journal of Agricultural Science. 4(9). September: 236-243.

Sharma, Amod. 2014. Sustainable economic analysis and extent of satisfaction level of King Chilli growers in Nagaland. Agriculture for Sustainable Development. 2(1). June: 188-191.

Sharma, Amod; Kichu, Yimkumba and Chaturvedi, B. K. 2016. Economics and Constraints of Pineapple Cultivation in Dimapur District of Nagaland. TJRAR. 16(1). January: 72-75.

Sharma, Amod; Kichu, Yimkumba and Sharma, Pradeep. Kumar. 2018. Sustainable economic analysis and constraints faced by the pineapple growers in Nagaland. Progressive Agriculture. 18(1). February: 27-33.
Sharma, Rajan, Chauhan, Jitendra., Meena, B. S. and Chauhan, R. S. 2015. Problems Experienced By Farmers and Project Officers in Watershed Management. Indian Research Journal of Extension Education. 15(2\&3): 23-27.

Shuya, Keviu and Sharma, Amod. 2014. Impact and constraints faced by the borrowers of cooperative bank finance in Nagaland. Economic Affairs. 59(4). October: 561-567.

Shuya, Keviu and Sharma, Amod. 2018. Problems faced by the Borrowers in Utilization and Acquiring of Cooperative Bank Loans in Nagaland. IJED. 14(2). April-June: 52-56.

Tangjang, Avicha and Sharma, Amod. 2018. Problem faced by the Large Cardamom Growers during production and marketing: A case study of Tirap district of Arunachal Pradesh. IJCMAS. 7(5). May: 2561-2573.

Walling, Imti and Sharma, Amod. 2015. Impact of SGRY on beneficiaries and non-beneficiaries in Dimapur district of Nagaland. TJRAR. 15(2). August: 9094.

Walling, Imti; Sharma, Amod; Yadav, Mukesh. Kumar; Rajbhar, Arun, Kumar and Kalai, Kankabati. 2017. Impact of Agricultural Technology Management Agency on Rural Economy of Nagaland, India. Plant Archiver. 17(2). October: 1511-1516.

\section{How to cite this article:}

Kanitoli Chishi, S. and Amod Sharma. 2018. Socio-Economic and Constraints Status of Impact of Integrated Watershed Development Programme in Nagaland, India. Int.J.Curr.Microbiol.App.Sci. 7(11): 1538-1546. doi: https://doi.org/10.20546/ijcmas.2018.711.177 